\title{
DEVELOPING COMPETENCIES FOR DRUG DEMAND REDUCTION
}

\author{
Isabel Amélia Costa Mendes ${ }^{1}$ \\ Maria Helena Palucci Marziale ${ }^{2}$
}

Since the last quarter of the 20th Century, public policies in different countries have highlighted the goal of reducing the demand for legal and illegal drugs. The same orientation is followed by international organizations which, allied to governments, are developing programs to facilitate the achievement of this goal. Among these, the World Health Organization stands out.

On the American continent, in addition to WHO - represented by its regional office - Pan-American Health Organization (PAHO), whose headquarters are located in Washington - and its representations in 35 countries in the region, the Organization of American States (OAS) also plays a prominent role. This organization has a strategy of training and motivating professionals to work towards drug demand reduction, complementing other initiatives of countries in the American region. In the context of OAS, the function of the Inter-American Drug Abuse Control Commission - CICAD - is to put forth this strategy. Since 1996, it has significantly contributed to the training of specialized professionals to work with and lead programs and actions aiming for drugs demand reduction.

Based on an experimental project applied in Latin-American Nursing Schools, selected by their academic profile, CICAD/OAS joined with these institutions to coordinate the project and be responsible for academic, administrative and logistic actions. On the other side, CICAD/OAS assumed the political and financial coordination, collecting funding for the implementation of the project, articulating with participant institutions, governments and financial sources, to present the results of each project developed; this articulation involves the selection of key professionals who receive the investment and assume the commitment and responsibility to work as multipliers in their countries of origin $^{(1-5)}$.

Under the leadership of its Psychiatric Nursing and Human Sciences Department, the College of Nursing at the University of São Paulo at Ribeirão Preto, WHO Collaborating Centre for Nursing Research Development (EERP-USP/CCOMS) has worked on the pioneer project of the on-line specialization program in research training about the Drugs Phenomenon - PREINVEST since 2002.

After the experience of the on-site course to two groups of nurses, with 18 students in 2002/2003 and 15 students 2003/2004 [originated from 10 Latin-American countries (Brazil, Argentina, Bolivia, Chile, Colombia, Ecuador, Mexico, Peru, Venezuela)], the institution innovated in 2005 and adopted the distance learning format, demanding considerable investment by all parties involved: management by the program coordinator at CICAD, Dr.. Maria da Glória Miotto Wright, institutional management at the University of Sao Paulo at Ribeirão Preto College of Nursing, and especially the course coordinator, Dr. Margarita Antônia Villar Luís, in addition to technicians and faculty involved. The on-site part of the program in Ribeirão Preto, Brazil was maintained, which resulted in a rich experience for the students and professionals directly involved (coordinators, faculty, computer technicians, tutors and advisors), influencing the entire community of the executive institution, which accompanied its first institutional distance learning experience (not only from the College of Nursing but also from the University of Sao Paulo at Ribeirão Preto) in a specialization program of these dimensions in terms of duration, scope and socio-political impact. The first version, offered in 2005/2006, included 33 students, with 30 nurses, two psychologists and one physician, from the following countries: Argentina (2), Bolivia (3), Brazil (5), Chile (3), Colombia (2), Ecuador (3), Honduras (3), Mexico (7), Peru (3), Venezuela (2). The second version, offered in 2006/2007, received 33 new participants, with 28 nurses, two sociologists and three psychologists, coming from: Argentina (1), Bolivia (3), Brazil (3), Chile (2), Colombia (2), Costa Rica (3) Ecuador (3), Honduras (2), México (4), Peru (4), Venezuela (1), and also Angola (1), Cape Verde (2) and Mozambique (2).

It is worth mentioning that the scope of the program evolved both in terms of target professionals and geographical origin, because other health professionals and the Caribbean were included as from the first online version, and Portuguese-speaking countries in Africa as from the second. 
This supplement of the Latin American Journal of Nursing (RLAE) includes articles of alumni from the first and second versions. Thus, for the forth time, RLAE joins this movement that involves professionals and institutions from several countries, contributing to the execution of a clear alcohol and drugs demand reduction policy, with preventive actions involving decentralization in cities, attempting to involve the organized civil society, giving priority to the most vulnerable communities, developing human resources with competences in the specialty area, promoting inter-disciplinary and continued actions, including contents on the topic in the curricula and disseminating research results originated from these efforts.

Through this journal, the product of a prolific partnership between OAS/CICAD and EERP-USP/CCOMS is perpetuated, working towards the development of competencies in human resources in health for the control of drugs abuse. Credits and acknowledgments to OAS, as well as to the National Anti-drug Secretary (SENAD) of the Presidency of the Federative Republic of Brazil, for their investment and trust vested in our institution.

This issue is composed of 21 articles in the printed version in English and in the on-line version in English, Portuguese and Spanish, with free access available on: http://www.scielo.br/rlae.

\section{REFERENCES}

1. Mendes IAC, Luis MAV. Uso de substâncias psicoativas, um novo velho desafio. Rev. Latino-Am. Enfermagem [periódico na Internet]. $2004 \mathrm{Abr}$ [citado 2008 Jan 15]; 12(spe): 295-300. Disponível em: http://www.scielo.br/ scielo.php?script=sci_arttext\&pid=S0104-11692004000700001\&lng=pt\&nrm=iso. doi: 11692004000700001 .

2. Wright MGM, Chisman AMcG, Mendes IAC, Luis MAV, Carvalho EC, Mamede MV. O papel da cooperação técnica \& financeiro para avançar a profissão de enfermagem na área de redução da demanda na América Latina: desafios e perspectivas. Rev. Latino-Am. Enfermagem [periódico na Internet]. 2004 Abr [citado 2008 Jan 15]; 12(spe): 301-306. Disponível em: http:// www.scielo.br/scielo.php?script=sci_arttext\&pid=S0104-11692004000700002\&Ing=pt\&nrm=iso. doi: $10.1590 / S 0104-$ 11692004000700002 .

3. Mendes IAC. A integração da enfermagem na América Latina e os desafios no preparo de lideranças para o desenvolvimento de pesquisas na área de drogas. Rev. Latino-Am. Enfermagem [periódico na Internet]. 2005 Out [citado 2008 Jan 15]; 13(spe): 765-770. Disponível em: http://www.scielo.br/scielo.php?script=sci_arttext\&pid=S0104-11692005000700001\& Ing=pt\&nrm=iso. doi: 10.1590/S0104-11692005000700001.

4. Mendes IAC, Villar LMA. Parcerias interinstitucionais: o investimento na construção de projetos multicêntricos sobre drogas lícitas e ilícitas. Rev. Latino-Am. Enfermagem [periódico na Internet]. 2005 Dez [citado 2008 Jan 15]; 13(spe2): 1164-1168. Disponível em: http://www.scielo.br/scielo.php?script=sci_arttext\&pid=S0104-11692005000800001\& Ing=pt\&nrm=iso. doi: 10.1590/S0104-11692005000800001.

5. Wright MGM, Caufield C, Gray G, Olson J. Programas internacionais de capacitação em pesquisa para enfermeiros no estudo do fenômeno das drogas na América Latina: desafios e perspectivas. Rev. Latino-Am. Enfermagem [periódico na Internet]. 2005 Dez [citado 2008 Jan 15]; 13(spe2): 1095-1101. Disponível em: http://www.scielo.br/scielo.php?script= sci_arttext\&pid=S0104-11692005000800002\&Ing=pt\&nrm=iso. doi: 10.1590/S0104-11692005000800002. 